\title{
The Effectiveness of Salavadora Persica (Siwak) Petroleum Ether Extract As An Intracanal Medicament Used in Endodontic Therapy: An In Vitro Study
}

\author{
Nahla Ayoub ( $\nabla$ naayoub@uqu.edu.sa ) \\ Umm al-Qura University \\ Nadia Badr \\ Umm al-Qura University \\ Saeed Alghamdi \\ Umm al-Qura University \\ Arwa Alzahrani \\ Umm al-Qura University \\ Rahaf Alsulimani \\ Umm al-Qura University \\ Afnan Nassar \\ Umm al-Qura University \\ Rawabi Qadi \\ Umm al-Qura University \\ Noha Swilam \\ British University in Egypt \\ Ibtesam Afifi \\ Tanta University
}

\section{Research Article}

Keywords: Salavadora persica L., GC/MS analysis, antimicrobial activity, Enterococcus faecalis, root canal treatment, intracanal medicament

Posted Date: February 23rd, 2021

DOl: https://doi.org/10.21203/rs.3.rs-219563/v1

License: (c) (1) This work is licensed under a Creative Commons Attribution 4.0 International License.

Read Full License 

${ }^{1}$ Department of Pharmacology and Toxicology, Faculty of Medicine, Umm Al-Qura

8 University (UQU), KSA.

$9 \quad{ }^{2}$ Department of Dental Biomaterials, Faculty of Dentistry, Umm Al-Qura University (UQU), KSA.

$11{ }^{3}$ Dental students, Faculty of Dentistry, Umm Al-Qura University (UQU), KSA.

$12{ }^{4}$ Department of Public Health, Faculty of Dentistry, Umm Al-Qura University 13 (UQU), KSA.

$14{ }^{5}$ Department of Pharmacognosy, Faculty of Pharmacy, British University in Egypt.

$15{ }^{6}$ Department of Medical Microbiology and Immunology, Faculty of Dentistry, Umm 16 Al-Qura University (UQU), KSA.

$17{ }^{7}$ Department of Medical Microbiology and Immunology, Faculty of Dentistry, Tanta 18 University, Egypt.

$21 \dagger$ These authors contributed equally to this work: Arwa Alzahrani3*†, Rahaf 22 Alsulimani $3 * \dagger$

$23 \quad$ Noha Swilam ${ }^{5 \ddagger}$, Ibtesam Afifi6 $6^{6,7}$, also contributed equally to this work

$24 *$ naayoub@uqu.edu.sa 
* Corresponding author

28 Prof. Nahla Ayoub

29 Department of Pharmacology and Toxicology, Faculty of Medicine, Umm Al-Qura 30 University (UQU), KSA.

31 Abidiyyah, Makkah, PO Box 715

32 Phone: +966 (2) 5501000

33 Email: naayoub@uqu.edu.sa 


\section{Abstract}

Background: Salvadora persica L. (Siwak) of the family Salvadoraceae has been used for many centuries as oral hygiene tools, particularly in Saudi Arabia. The current study aimed at developing a new root canal medicament based on the extract of Salvadora persica (SP). The antibacterial activity against Enterococcus faecalis was determined compared with the gold standard intracanal medicament, $\mathrm{Ca}$ $(\mathrm{OH})_{2}$. Materials and Methods: Freeze-dried Siwak sticks were extracted with Petroleum ether to yield an oily extract (SPE). GC-MS analysis was carried out to identify SPE components, whereas 32 compounds were identified (89.09\%), with main components of benzyl isothiocyanate (BITC) (33.32\%) and steroids (34\%). Firstly, the consistency of the experimental medicament was accomplished according to ANSI/ADA Specification no 57. SPE assessment as intracanal medicament was conducted through an in vitro assay on 45 single-rooted mandibular premolars inoculated of $5 \mu \mathrm{L}$ of E. faecalis. Colony-forming units (CFU) were counted before the application of experimental intracanal medicament (CFU-1) and then after seven days of its application (CFU-2). Group I: Siwak extract-based intracanal medicament, Group II positive control group received $\mathrm{Ca}(\mathrm{OH})_{2}$ paste, and Group III: negative control group received no medication. Results: CFU before and after using Siwak based medicament recorded statistically significant reduction $(\mathrm{P}=0.006)$ as well as those of Group II when $\mathrm{Ca}(\mathrm{OH})_{2}$ was applied $(P=0.01)$. On comparing both medicaments with Group III, there were significant differences; $(P=0.00)$ and $(P=0.007)$, respectively. Siwak oil extract-based medication proved complete eradication of E. faecalis. Conclusion: SPE has a good potential as an intracanal medicament, besides the cleaning and shaping during endodontic therapy. This finding could be referred to as the high content of BITC bactericidal against pulpal 
59 and periodontal pathogens, in synergism with other antimicrobial components, 60 representing $70.71 \%$ of SP oil extract.

61

62 Keywords: Salavadora persica L., GC/MS analysis, antimicrobial activity, 63 Enterococcus faecalis, root canal treatment, intracanal medicament. 


\section{Introduction}

The ultimate goal of an infected root canal preparation, including cleaning, shaping, and using the disinfectant solution, is to entirely remove bacteria, their byproduct, and pulpal remnants. The microorganisms in the root canal of the teeth are principally responsible for pulpal/periapical diseases. These microorganisms can survive and cause reinfection in the root canal with complex anatomy [1]. The pathological bacteria of root canals include ( Streptococcus sanguinis, Streptococcus mutans, Enterococcus faecalis, Fusobacterium nucleatum, Porphyromonas gingivalis, and Prevotella intermedia) [2]; however, the most causative species is Enterococcus faecalis $[3,4]$. During multiple endodontic treatment visits, the intracanal medication is used to eradicate bacteria in adults and children's root canal systems. Accordingly, the pain and inflammation of pulpal and periapical tissues are reduced. This represents an optimal root canal disinfection protocol that guarantees a high success rate of root canal treatment. $[5,6]$. The most commonly used intracanal medicament is calcium hydroxide $\mathrm{Ca}(\mathrm{OH})_{2}$ because of its significant bactericidal effect and inhibition of inflammatory exudates [7].

There has been prosperity in phytotherapy and naturopathic medicine to treat the diseases due to their established properties of biocompatibility and availability [8]. Salvadora persica L. (Siwak, SP) is a plant whose roots, twigs, or stems have been used for many centuries as oral hygiene tools, particularly in Saudi Arabia. Using Siwak (tooth stick) for cleaning of mouth is advocated Islamic well-established beliefs. Recently, SPE proved an evidenced biocompatibility and antibacterial effect after histopathological and immunohistochemical investigation [9-12].

Many studies have been demonstrated that extracts of SP possess various antiplaque, antiperiopathic, anticaries, anti-inflammatory, and antimycotic effects [13, 14]. 
89 Extracts of SP also significantly affect intracanal irrigant both in vitro and in vivo $[11,15]$ because of its inhibitory effect on oral pathogen growth $[16,17]$. According to the available literature, the target of root canal treatment (RCT) is to eradicate bacteria in the root canal system; the present study was designed as randomized control in vitro study to assess the effect of an experimental intracanal medicament based on SPE on the most causative bacteria for endodontic pulpitis/periodontitis; Enterococcus faecalis. The gold standard intracanal medicament $\mathrm{Ca}(\mathrm{OH})_{2}$ was employed as control.

\section{Materials and method}

\section{Materials:}

The materials used in this study were Salvadora persica (Siwak, SP) sticks brought from Riyadh region in Saudi Arabia, Zinc oxide powder (Prevest DentPro Limited, unit II, Bari Brahmana, Jammus-181133, India), and $\mathrm{Ca}(\mathrm{OH})_{2}$ endodontic medicament (MetaPaste) (META BIOMED CO.LTD., Korea)

The sticks of cultivated Salvadora persica SP (namely Miswak, Siwak or Arak) plant were collected from Riyadh region in Saudi Arabia. The plant was identified by Dr. Talal Dahan [18] and a voucher specimen (\# 19750) was deposited in properly labeled polythene bags for future reference at the Herbarium Centre, College of Pharmacy, UQU, Saudi Arabia. The authors followed IUCN Policy Statement on Research Involving Species at Risk of Extinction.

\section{Methods:}

\section{Preparation of SP petroleum ether extract (SPE)}

The fresh plant sticks were freeze-dried and then ground to a fine powder using a commercially available food blender. The ground sample (500 g) was used to prepare 
the extract. Consequently, petroleum ether extract was prepared by cold percolating $500 \mathrm{~g}$ of dried powder of the plant sticks in one $\mathrm{L}$ of petroleum ether for $72 \mathrm{~h}$, and every $24 \mathrm{~h}$ fresh solvent was used. The solvent was removed and recovered in a rotary evaporator (BÜCHI Rotavapor RII, Büchi Labortechnik; Flawil, Switzerland) at 40 ${ }^{\circ} \mathrm{C}$ using a BÜCHI vacuum pump. At the last stage, the oily extract was freeze-dried to ensure that solvents were removed to yield $20 \mathrm{~mL}$ of an oily material (SP oil extract) with a powerful aromatic odor. SP oil extract was kept in a brown screwcapped tube in a $-20{ }^{\circ} \mathrm{C}$ freezer until further analysis.

\section{GC/MS Analysis}

Mass spectra were recorded using Shimadzu GCMS-QP2010 (Kyoto, Japan) equipped with Rtx-5MS fused bonded column (30 m x $0.25 \mathrm{~mm}$ i.d. x $0.25 \mu \mathrm{m}$ film thickness) (Restek, USA) and a split-splitless injector. The initial column temperature was kept at $50{ }^{\circ} \mathrm{C}$ for $3 \mathrm{~min}$ (isothermal) and programmed to $300{ }^{\circ} \mathrm{C}$ at a rate of $5{ }^{\circ} \mathrm{C} / \mathrm{min}$, and kept constant at $300{ }^{\circ} \mathrm{C}$ for $10 \mathrm{~min}$ (isothermal). Injector temperature was $280{ }^{\circ} \mathrm{C}$. Helium carrier gas flow rate was $1.37 \mathrm{~mL} / \mathrm{min}$. All the mass spectra were recorded applying the following condition: (equipment current) filament emission current, 60 $\mathrm{mA}$; ionization voltage, $70 \mathrm{eV}$; ion source, $220{ }^{\circ} \mathrm{C}$. Diluted samples $(1 \% \mathrm{v} / \mathrm{v})$ were injected with split mode (split ratio) 1: 15.

\section{Compounds identification}

The identification of compounds was performed based on their retention indices relative to a homologous series of n-alkanes (C8-C28) injected under the same conditions and matching their mass spectra with National Institute of Standards and Technology (NIST) and Wiley library database as well as literature [19-23]

\section{Collection of extracted teeth}


The sample size for antimicrobial activity test was calculated based on data from an internal pilot study using $G^{*}$ Power version 3.1.9.2 for sample size analysis at $\alpha=0.05$ and $80 \%$ power which yielded a sample size of 15 samples/group. Forty-five single root premolars extracted teeth for periodontal or orthodontic reasons were obtained from the department of oral surgery at a different governmental and private hospital in Makkah city, Saudi Arabia. Teeth with previous endodontic therapy, fracture, crack, resorption, and root caries were excluded from the study. The present study followed the ethical guidelines for clinical investigation: ethical policy of the American Dental Association regarding the use of human subjects in clinical research and approved by the Institutional Review Board (IRB), Faculty of Dentistry, Umm Al-Qura University, KSA, (IRB \# 122-19).

\section{Preparation of the experimental Siwak-based extract endodontic medicament}

\section{Determination of consistency:}

The first intended procedure was to determine the appropriate Powder/Liquid mixing ratio (Zinc oxide powder/ Siwak extract) for the experimental endodontic medicament. The purpose was to obtain a smooth and homogeneous material whose consistency is acceptable for clinical application. The consistency was comparable to the endodontic medicament used as a control, commercial calcium hydroxide paste.

Siwak oil extract was mixed with the zinc-oxide powder at different ratios till reaching the appropriate consistency compared to the control endodontic medicament (MetaPaste) using the one-inch string method. [24]. Some drops of the extract were placed on a clean glass slab, and the powder was added gradually using a clean stainless spatula. Various amounts of the extract and zinc oxide powder were mixed till obtaining the proper consistency. The paste was creamy in consistency but quite 
heavy and stringed out at least an inch $(2.5 \mathrm{~mm})$ when the spatula is lifted from the mix. The adequate consistency was chosen, and its powder and liquid quantities were determined. It was found that one scoop of zinc oxide powder mixed with one drop of the Siwak oil extract resulted in the required consistency.

\section{Preparation of extracted tooth}

All 45 single-rooted premolars were decoronated to standardize their root length. The working length was established to be $14-16 \mathrm{~mm}$ and the roots was undergone rotary standardized instrumentation up to X3-ProTaper Next (Dentsply-Maillefer, Switzerland). An irrigant $2.5 \% \mathrm{NaOCl}$ was used after each instrument and finally dried with size 25 absorbent paper points. Each root was placed in a closed test tube containing $3 \mathrm{~mL}$ of brain heart infusion (BHI) broth (SPML - Saudi Prepared Media Laboratory Co. Ltd.) and sterilized by autoclaving at $121^{\circ} \mathrm{C}$ for $20 \mathrm{~min}$ then incubated for $24 \mathrm{~h}$ at $37^{\circ} \mathrm{C}$ to confirm sterility by absence of turbidity

\section{Preparation of Enterococcus faecalis suspension}

Enterococcus faecalis ATCC 29212 strain was grown on Bile Esculin agar media (SPML - Saudi Prepared Media Laboratory Co. Ltd.) at $37{ }^{\circ} \mathrm{C}$ for 24 h. After growth, bacterial suspension was prepared from grown bacterial colonies by inoculation in Brain Heart Infusion (BHI) broth and adjusted to the optical density of approximately $1.5 \times 108 \mathrm{CFU} / \mathrm{mL}$ by comparing its turbidity to a $0.5 \mathrm{McFarland}$ standard spectrophotometrically.

\section{Contamination of root canals:}

Two $\mathrm{mL}$ of sterile BHI broth was removed from each root containing tube and replaced by $2 \mathrm{~mL}$ of the prepared bacterial suspension. The tubes were then closed and incubated at $37^{\circ} \mathrm{C}$ for $48 \mathrm{~h}$. 


\section{Colony forming units one (CFU-1)}

After $48 \mathrm{~h}$ predetermined contamination period of root canals was elapsed, each root was removed from the tube under complete aseptic precautions and irrigated with sterile saline $(100 \mu \mathrm{L})$. Later, a dry sterile absorbent paper point size 25 was inserted into the root canal and left for $5 \mathrm{~min}$. Afterwards, these paper points were transferred individually to sterile test tubes, each containing $1 \mathrm{~mL}$ of sterile saline solution, vortexed for $30 \mathrm{sec}$, and then four serial dilutions were made for each tube. Aliquots of $10 \mu \mathrm{L}$ of each dilution were plated onto Bile Esculin (BE) agar plates and incubated at $37{ }^{\circ} \mathrm{C}$ for $24 \mathrm{~h}$. The grown bacterial colonies were counted and multiplied by their dilution factor to represent CFU-1 / mL.

\section{Ex vivo testing of antimicrobial activity of the experimental medicaments}

The 45 decoronated teeth were randomly allocated into 3 groups by simple random sampling using random digit table depending on medicament used: Group I $(n=16)$ : Experimental Siwak extract based- medicament. Group II (n=16): $\mathrm{Ca}(\mathrm{OH})_{2}$ paste (positive control).

Group III $(n=13)$ : sterile physiological saline as negative control group.

Medicaments were placed into root canals with lentulo spiral inserted to the full working length. The root canal foramina were sealed by sterile cotton pellets and the orifices closed by temporary restoration; then, the samples were kept in an incubator at $37^{\circ} \mathrm{C}$ for seven days.

\section{Colony forming units-2 (CFU-2)}

Seven days later, each root was irrigated with sterile normal saline then the previous technique was repeated to obtain CFU-2.

\section{Statistical analysis:}


Data were collected, tabulated, and statistically analyzed using Statistical Package for Social Science (SPSS v.20). $\mathrm{P}<0.05$ was considered as a level of significance. The Mean and standard deviation were tabulated and statistically analyzed using one-way ANOVA test regarding the CFU 1 of the three tested groups before using intracanal medication. Regarding the CFU- 2 of three groups, the mean and standard deviation were analyzed using One-Way non-parametric ANOVA (Kruskal-Wallis). Finally, the antimicrobial effect of different tested medications on Enterococcus faecalis was tabulated and statistically analyzed using Paired t-test.

\section{Results:}

\section{Chemical composition of SP oil extract}

Analysis of the SP oil extract by GC and GC/MS revealed that SP oil extract contained 32 compounds, of which benzyl isothiocyanate (33.32\%), $\gamma$-sitosterol (25.76\%), stigmasterol (5.92\%), $\beta$-sitosterol acetate (2.28\%), $n$-hexadecanoic acid (4.27\%) and (Z)-11-octadecenoic acid (3.16\%) were found to be the major constituents. Compounds are listed in order of their elution times on Rtx-5MS 224 column; Table 1.

\section{Salvadora persica oil extract endodontic therapy}

The statistical analysis of the CFU-1 of three tested groups before using intracanal medication was tabulated in Table 2. It was evident that there were no significant differences in bacterial counts among them $(P=0.359)$. Table 3 and Fig. 1 show the statistical analysis using Paired t-test of the number of the colony forming units of

230 Enterococcus faecalis before and after applying the investigated medicaments at the root canal lumens; CFU-1 and CFU-2, respectively. The results showed a significant difference between CFU-1 and CFU-2 either in using experimental medicaments 
Siwak oil-based medicament $(P=0.006)$ or $\mathrm{Ca}(\mathrm{OH})_{2}$ medicament $(P=0.011)$. On the other hand, the bacterial count of negative control group showed a nonsignificant difference between CFU-1 and CFU-2 $(P=0.438)$. Finally, the bacterial count's significant difference among the three tested groups was compared using one-way non-parametric ANOVA; Table 4. The values were insignificant difference between bacterial count after using the experimental SPE and $\mathrm{Ca}(\mathrm{OH})_{2}$ medicaments $(P=0.210)$. On the contrary, comparing both medicaments with negative control saline group, resulted in significant differences; $(P=0.00)$ and $(P=0.007)$, respectively.

\section{Discussion}

The chemomechanical cleaning and shaping of the root canals of the teeth are essential for the success of endodontic therapy [25, 26]. This combination of mechanical preparation with disinfection is effective in reducing bacterial counts. Yet, intracanal medication is a crucial procedure during root canal treatment [27].

In fact, the intention of root canal treatment is to eradicate bacteria and their byproducts from the root canal system [28]. It is well documented that the use of biocompatible intracanal medications possessing antimicrobial properties between appointments destroy and eradicate bacteria in the root canal system. Consequently, the probability of success of root canal treatment would be significantly intensified [29]. It was proven that Enterococcus faecalis is the most predominant bacteria found in the infected root canal. Unfortunately, this species has the ability to survive in hard environment and implies a challenge to be completely exterminated from root canal system [30].

Calcium hydroxide is the gold standard intracanal medication used in the treatment of infected root canals, referring to its well-known antibacterial features and ease of 
application [31]. Therefore, the present study compared the antimicrobial effect of the experimental intracanal medicament based on SPE to that of $\mathrm{Ca}(\mathrm{OH})_{2}$. The effect of both medicaments against Enterococcus faecalis was considered in the presence of a negative control group, saline, to specify the antimicrobial effect efficiently. In reality, $\mathrm{Ca}(\mathrm{OH})_{2}$ is the most commonly used intracanal medicament and represents the first choice by dentists; Athanassiadis et al , Asnaashari, $M$ et al [31, 32]. However, the antimicrobial effect of the experimental medicament SPEinsignificantly surpasses that of $\mathrm{Ca}(\mathrm{OH})_{2}(P=0.210)$; Table 3. In the present investigation, SPEexperimental intracanal medicament; (Group 1) proved an effective eradication of Enterococcus faecalis. This finding was in agreement with the results of Al Qarni et al., in 2019, who reported the usefulness of Siwak extract as endodontic irrigant against $E$. faecalis [33]. As well, it was evidenced that Salvadora persica has an inhibitory effect on the growth of the oral pathogen [34].

In this study, the chemical profile representing 32 compounds of Salvadora persica petroleum ether extract were analyzed, identified by GC/MS (89.09\%) are listed in Table 1. The main component was found to be benzyl isothiocyanate (BITC) (33.32\%). This component was reported as the most robust antibacterial component with high bactericidal activity against Gram-negative periodontal pathogens [35]. The potent antibacterial effect of the experimental medicament; Table 3, suggested that SPEtargeted the bacterial membrane, whereas BITC has both lipophilic and electrophilic properties. It is reported that BITC penetrates through the outer bacterial membrane and possibly interfered with the bacterial redox systems, thus hampering the bacterium's ability to maintain its membrane potential. Such an effect of BITC has been demonstrated for mitochondrial membranes [36]. 
In addition, there are $\gamma$-sitosterol (25.76\%), $n$-hexadecanoic acid (4.27\%) and (Z)-11-

282 octadecenoic acid (3.16\%) are reported to as potent broad spectrum antimicrobial [3741]. Moreover, it has been demonstrated that the SP extracts have antimicrobial effect and inhibited both Gram-positive and Gram-negative bacteria because the presence of carvacrol ( 0.57\%) which is confirmed by Memar, M.Y., et al, 2017 [42]. Siwak extract components Table 1 showed the presence of $n$-tetradecane $(0.21 \%), n$ hexadecane $(0.13 \%)$, 11-octadecenoic acid $(3.16 \%)$, squalene $(0.17 \%)$, stigmasterol $(0.12 \%)$, sitosterol $(2.28 \%)$ and sitostenone $(0.54 \%)$. These components are potent antibacterial agents [43-49]. Therefore, Siwak petroleum ether extract's strong bactericidal effect is attributed to the antimicrobial compounds representing a percentage of $70.71 \%$ of the extract. It is worthy to mention that some components with anti-inflammatory and antioxidant effect are detected such as oleic acid (1.95\%),11-octadecenoic acid (3.16\%), 2,2'-methylenebis (6-tert-butyl-4methylphenol $\quad(0.13 \%), \quad$ squalene $\quad(0.17 \%), n$-benzyloleamide $\quad(0.53 \%), n$ benzylpalmitamide $(0.36 \%)$ stigmasta-5, 22-dien-3-ol (0.65\%) lupeol (1.24\%) and hexadecanoic acid, ethyl ester (0.13\%) [45- 47] [50-55]. Besides, the use of zinc oxide powder might also contribute to the inhibitory effect of several oral pathogens[56]. Zinc as a metal has been used as bactericidal and bacteriostatic agents [57].

\section{Conclusion}

Referring to the present investigation findings, the authors report that a novel intracanal medicament based on Salvadora persica petroleum ether extract can be used efficaciously in endodontic therapy. Besides the regular cleaning and shaping procedures, this experimental endodontic medicament can eradicate the bacteria and their byproducts exclusively from the root canal system owing to its proficient antibacterial action. 
307 The authors would like to thank the Deanship of Scientific Research at Umm Al-Qura

308 University for supporting this work by Grant Code: 19-MED-1-03-0010.

309 The authors would like to thank also Dr. Hamad Almuiaqly for his help in data 310 collection and the laboratory specialist: Munirah Hadadi and Alaa AlKhotani for 311 providing all facility that was required in the lab.

\section{Author contributions}

313 A.A., R.A., R.Q. A.N, N.S. and I.A. methodology, validation, wrote the main 314 manuscript, N.A., N.B., and S.A. designed the study, prepared the tables and figures, 315 revised the manuscript.

\section{Additional information}

317 Funding: This research is fully funded by DSR at UQU, KSA. Grant Code: 19318 MED-1-03-0010.

319 Competing interests: The authors declare no competing interests

320 Data availability: The datasets analysed during the current study are available from 321 the corresponding author on reasonable request. 


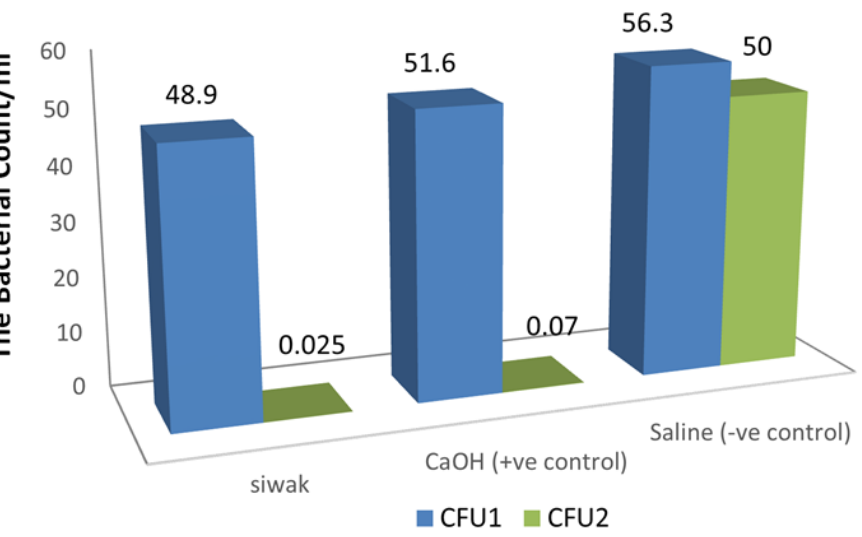

The Investigated Groups

324 Figure 1: A histogram representing $\mathrm{CFU} / \mathrm{mL}^{*} 10^{4}$ before and after application of intracanal medicaments 
326 Table (1): The chemical profile of Salvadora persica petroleum ether extract

\begin{tabular}{|c|c|c|c|c|c|c|c|}
\hline $\begin{array}{c}\text { Peak } \\
\#\end{array}$ & $\mathbf{R}_{\mathbf{t}}$ & Component & $\begin{array}{l}\text { Molecular } \\
\text { formula }\end{array}$ & $R I_{\text {exp }}{ }^{a}$ & $\boldsymbol{R I} \boldsymbol{I}_{i t}^{b}$ & $\begin{array}{c}\text { Content } \\
(\%)\end{array}$ & Identification $^{\mathrm{c}}$ \\
\hline 1. & 18.35 & Carvacrol & $\mathrm{C}_{10} \mathrm{H}_{14} \mathrm{O}$ & 1288 & 1288 & 0.57 & MS, KI \\
\hline 2. & 20.47 & Benzyl Isothiocyanate & $\mathrm{C}_{8} \mathrm{H}_{7} \mathrm{NS}$ & 1361 & 1359 & 33.32 & MS, KI \\
\hline 3. & 21.14 & $n$-Tetradecane & $\mathrm{C}_{14} \mathrm{H}_{30}$ & 1384 & 1400 & 0.21 & MS, KI \\
\hline 4. & 23.76 & $n$-Pentadecane & $\mathrm{C}_{15} \mathrm{H}_{32}$ & 1485 & 1500 & 0.38 & MS, KI \\
\hline 5. & 26.24 & $n$-Hexadecane & $\mathrm{C}_{16} \mathrm{H}_{34}$ & 1582 & 1600 & 0.13 & MS, KI \\
\hline 6. & 34.40 & $\begin{array}{l}n \text {-Hexadecanoic acid } \\
\text { (Palmitic acid) }\end{array}$ & $\mathrm{C}_{16} \mathrm{H}_{32} \mathrm{O}_{2}$ & 1948 & 1946 & 4.27 & MS, KI \\
\hline 7. & 34.91 & $\begin{array}{l}\text { Hexadecanoic acid ethyl } \\
\text { ester }\end{array}$ & $\mathrm{C}_{18} \mathrm{H}_{36} \mathrm{O}_{2}$ & 1972 & 1975 & 0.13 & MS, KI \\
\hline 8. & 36.12 & Cyclic octaatomic sulphur & $\mathrm{S}_{8}$ & 2034 & 2055 & 0.99 & MS, KI \\
\hline 9. & 37.86 & Oleic Acid & $\mathrm{C}_{18} \mathrm{H}_{34} \mathrm{O}_{2}$ & 2130 & 2130 & 1.95 & MS, KI \\
\hline 10. & 37.92 & (Z)-11-Octadecenoic acid & $\mathrm{C}_{18} \mathrm{H}_{34} \mathrm{O}_{2}$ & 2133 & 2117 & 3.16 & MS, KI \\
\hline 11. & 38.15 & (Z,Z)-9,12- & $\mathrm{C}_{18} \mathrm{H}_{31} \mathrm{ClO}$ & 2146 & 2139 & 0.37 & MS, KI \\
\hline & & $\begin{array}{l}\text { Octadecadienoyl chloride } \\
\text { (Linoleic acid chloride) }\end{array}$ & & & & & \\
\hline 12. & 38.24 & $\begin{array}{l}\text { (Z)-9-Octadecenoic acid } \\
\text { ethyl ester } \\
\text { (Oleic acid ethyl ester) }\end{array}$ & $\mathrm{C}_{20} \mathrm{H}_{38} \mathrm{O}_{2}$ & 2151 & 2168 & 0.45 & MS, KI \\
\hline 13. & 38.36 & $\begin{array}{l}\text { 9-Octadecenoic acid ethyl } \\
\text { ester }\end{array}$ & $\mathrm{C}_{20} \mathrm{H}_{38} \mathrm{O}_{2}$ & 2157 & 2171 & 0.14 & MS, KI \\
\hline 14. & 42.84 & $\begin{array}{l}p \text {-Cresol, 2,2'-methylene } \\
\text { bis [6-tert-butyl- }\end{array}$ & $\mathrm{C}_{23} \mathrm{H}_{32} \mathrm{O}_{2}$ & 2403 & 2398 & 0.13 & MS, KI \\
\hline 15. & 48.95 & Squalene & $\mathrm{C}_{30} \mathrm{H}_{50}$ & 2796 & 2814 & 0.17 & MS, KI \\
\hline 16. & 49.51 & N-Benzylpalmitamide & $\mathrm{C}_{23} \mathrm{H}_{39} \mathrm{NO}$ & 2832 & 2880 & 0.36 & MS \\
\hline
\end{tabular}




\begin{tabular}{|c|c|c|c|c|c|c|c|}
\hline 17. & 51.09 & Stigmasta-3,5-diene & $\mathrm{C}_{29} \mathrm{H}_{48}$ & 2934 & - & 0.77 & MS \\
\hline 18. & 51.69 & Stigmasterol acetate & $\mathrm{C}_{31} \mathrm{H}_{50} \mathrm{O}_{2}$ & 2972 & 2879 & 0.12 & MS, KI \\
\hline 19. & 51.87 & $\begin{array}{l}\text { 3 } \beta \text {-Acetoxystigmasta- } \\
\text { 4,6,22-triene }\end{array}$ & $\mathrm{C}_{31} \mathrm{H}_{48} \mathrm{O}_{2}$ & 2984 & - & 0.24 & MS \\
\hline 20. & 52.06 & $\begin{array}{l}n \text {-Benzyloctadecenamide } \\
\text { (n-Benzyloleamide) }\end{array}$ & $\mathrm{C}_{25} \mathrm{H}_{41} \mathrm{NO}$ & 2996 & 2991 & 0.53 & MS, KI \\
\hline 21. & 52.17 & $\begin{array}{l}\text { Stigmasta-5,22-dien-3-ol, } \\
\text { acetate }\end{array}$ & $\mathrm{C}_{31} \mathrm{H}_{50} \mathrm{O}_{2}$ & 3003 & - & 0.65 & MS \\
\hline 22. & 52.47 & Clionasterol acetate & $\mathrm{C}_{31} \mathrm{H}_{52} \mathrm{O}_{2}$ & 3022 & - & 0.50 & MS \\
\hline 23. & 52.66 & Stigmastan-3,5,22-triene & $\mathrm{C}_{29} \mathrm{H}_{46}$ & 3034 & 2981 & 1.89 & MS, KI \\
\hline 24. & 52.94 & $\beta$-Sitosterol acetate & $\mathrm{C}_{31} \mathrm{H}_{52} \mathrm{O}_{2}$ & 3052 & - & 2.28 & MS \\
\hline 25. & 53.28 & Cholesterol & $\mathrm{C}_{27} \mathrm{H}_{46} \mathrm{O}$ & 3074 & 3075 & 0.66 & MS, KI \\
\hline 26. & 54.89 & Campesterol & $\mathrm{C}_{28} \mathrm{H}_{48} \mathrm{O}$ & 3177 & 3131 & 0.70 & MS \\
\hline 27. & 55.40 & Stigmasterol & $\mathrm{C}_{29} \mathrm{H}_{48} \mathrm{O}$ & 3210 & 3213 & 5.92 & MS, KI \\
\hline 28. & 56.44 & $\gamma$-Sitosterol & $\mathrm{C}_{29} \mathrm{H}_{50} \mathrm{O}$ & 3277 & 3290 & 25.76 & MS, KI \\
\hline 29. & 57.47 & Unidentified & - & 3344 & - & 3.57 & - \\
\hline 30. & 58.21 & 3,5-Stigmastadien-7-one & $\mathrm{C}_{29} \mathrm{H}_{46} \mathrm{O}$ & 3391 & - & 0.56 & MS \\
\hline 31. & 59.04 & Sitostenone & $\mathrm{C}_{29} \mathrm{H}_{48} \mathrm{O}$ & 3444 & 3435 & 0.54 & MS, KI \\
\hline 32. & 60.19 & Lupeol & $\mathrm{C}_{30} \mathrm{H}_{50} \mathrm{O}$ & 3518 & 3451 & 1.24 & MS \\
\hline
\end{tabular}

\% Total identified

89.09

327

328 Compounds are listed in order of their elution times on Rtx-5MS column. ${ }^{\mathrm{a}} R I_{\text {exp }}$,

329 retention index determined experimentally relative to C8 - C28 n-alkanes on Rtx-

$3305 \mathrm{MS}$ column; ${ }^{\mathrm{b}} \mathrm{R} I_{\text {lit }}$, published retention indices; ${ }^{\mathrm{c}}$ Identification, was based on

331 comparison of the compounds' mass spectral data (MS) and retention indices (RI)

332 with those of NIST Mass Spectral Library (2017), Wiley Registry of Mass Spectral

333 Data $8^{\text {th }}$ edition and literature. 
334 Table (2): The mean and standard deviation of bacterial count of the tested groups

335 before application of the different intracanal medicament

\begin{tabular}{|c|c|c|c|c|c|}
\hline \multirow[b]{2}{*}{ Groups } & \multirow{2}{*}{$\begin{array}{c}\text { Group I } \\
\text { Siwak } \\
\text { Mean } \pm \text { SD }\end{array}$} & \multirow{2}{*}{$\begin{array}{c}\text { Group II } \\
\text { Ca(OH)2 } \\
\text { Mean } \pm \text { SD }\end{array}$} & \multirow{2}{*}{$\begin{array}{c}\text { Group III } \\
\text { Saline } \\
\text { Mean } \pm \text { SD }\end{array}$} & \multicolumn{2}{|c|}{ ANOVA } \\
\hline & & & & $\mathbf{F}$ & P-value \\
\hline CFU-1 & $48.9 \pm 53.7 * 10^{4}$ & $51.6 \pm 68.4 * 10^{4}$ & $56.3 \pm 59 * 10^{4}$ & 1.050 & 0.359 \\
\hline
\end{tabular}

336 
Table (3): The descriptive statistical analysis of the Enterococcus faecalis count

338 before (CFU-1) and after (CFU-2) the application of the medicaments

339

\begin{tabular}{|c|c|c|c|}
\hline Bacterial & & & Paired t test \\
\hline Groups & $\begin{array}{c}\text { CFU-1 } \\
\text { Mean } \pm \text { SD }\end{array}$ & $\begin{array}{c}\text { CFU-2 } \\
\text { Mean } \pm \text { SD }\end{array}$ & p-value \\
\hline $\begin{array}{c}\text { Group I } \\
\text { Siwak } \\
\end{array}$ & $48.9 \pm 53.7 * 10^{4}$ & $0.0250 \pm 0.1 * 10^{4}$ & 0.006 \\
\hline $\begin{array}{c}\text { Group II } \\
\text { CaOH (+ve control) }\end{array}$ & $51.6 \pm 68.4 * 10^{4}$ & $0.07 \pm 0.25^{*} 10^{4}$ & 0.011 \\
\hline $\begin{array}{c}\text { Group III } \\
\text { Saline (-ve control) }\end{array}$ & $56.3 \pm 59 * 10^{4}$ & $50 \pm 115^{*} 10^{4}$ & 0.438 \\
\hline
\end{tabular}


340 Table (4): Comparison between three different tested groups after the application of 341 the medicaments

\begin{tabular}{|c|c|c|c|}
\hline Groups & $\begin{array}{c}\text { Siwak } \\
\text { VS Ca(OH) }\end{array}$ & $\begin{array}{c}\text { Siwak } \\
\text { VS Saline }\end{array}$ & $\begin{array}{c}\mathbf{C a}(\mathbf{O H})_{2} \\
\text { VS Saline }\end{array}$ \\
\hline (P-value) & 0.210 & $0.00^{*}$ & $0.007^{*}$ \\
\hline
\end{tabular}


343 1. Siqueira Jr, J.F., K.M. Magalhães, and I.N. Rôças. Bacterial reduction in 344 infected root canals treated with $2.5 \% \mathrm{NaOCl}$ as an irrigant and calcium hydroxide/camphorated paramonochlorophenol paste as an intracanal dressing. Journal of endodontics, 33(6): p. 667-672 (2007). https://pubmed.ncbi.nlm.nih.gov/17509403/

2. Tan, K.S., et al., Rapid method for the detection of root canal bacteria in endodontic therapy. Journal of endodontics, 41(4): p. 447-450 (2015). https://europepmc.org/article/med/25576208

3. Kakehashi Stanley HR, F.R., The effects of surgical exposures of dental pulps in germ-free and conventional laboratory rats. Oral Surg Oral Med Oral Pathol., ;20:340-9 (1965). https://pubmed.ncbi.nlm.nih.gov/14342926/

4. Rôças, I.N., J.F. Siqueira Jr, and K.R. Santos, Association of Enterococcus faecalis with different forms of periradicular diseases. Journal of endodontics, 30(5): p. 315-320 (2004). https://pubmed.ncbi.nlm.nih.gov/15107642/

358 5. Bystrom, A., R. Claesson, and G. Sundqvist, The antibacterial effect of camphorated paramonochlorophenol, camphorated phenol and calcium hydroxide in the treatment of infected root canals. Endodontics \& dental traumatology, 1(5):

p.

170. https://onlinelibrary.wiley.com/doi/abs/10.1111/j.1600-9657.1985.tb00652.x

363 6. Ramos, I.F.d.A.S., et al., Histopathological analysis of corticosteroidantibiotic preparation and propolis paste formulation as intracanal medication 
after pulpectomy: an in vivo study. Journal of applied oral science, 20(1): p. 50-56. (2012). https://www.ncbi.nlm.nih.gov/pmc/articles/PMC3928772/

7. Portenier, I., et al., The susceptibility of starved, stationary phase, and growing cells of Enterococcus faecalis to endodontic medicaments. Journal of Endodontics, $\quad$ 31(5): $\quad$ p. $\quad 380-386$. (2005). https://pubmed.ncbi.nlm.nih.gov/15851934/

8. Sivakumar, A., et al., Herbendodontics-Phytotherapy In Endodontics: A Review. Biomedical and Pharmacology Journal, 11(2): p. 1073-1082. (2018). https://biomedpharmajournal.org/vol11no2/herbendodontics-phytotherapy-inendodontics-a-review/

9. Babay, N. and K. Almas, Effect of miswak extract on healthy human dentin: an in vitro study. Saudi Dent $J$, 11: p. 46-52. (1999). https://www.thejcdp.com/doi/pdf/10.5005/jcdp-3-3-27

10. Barkhordar, R.A., et al., Removal of intracanal smear by doxycycline in vitro. Oral Surgery, Oral Medicine, Oral Pathology, Oral Radiology, and Endodontology, 84(4): p. $420-423$ (1997). https://www.sciencedirect.com/science/article/abs/pii/S1079210497900421

11. Al-Sabawi, N.A., A. Al Sheikh Abdal, and M.Y. Taha, The antimicrobial activity of Salvadora persica solution (Miswak-Siwak) as root canal irrigant (a comparative study). Univ. Sharjah J. Pure Appl. Sci, 4(3): p. 69-91. (2007). https://www.ajrsp.com/en/Archive/issue-9/The-Antimicrobial-Activity-of$\underline{\text { Salvadora-Persica-Solution-as-Root-Canal-Irrigant.pdf }}$

12. Shafaie, L.A., Moubark., R., Biocompatibility and mutagenicity of Salvadora persica extract and Kaempherol implanted in the subcutaneous 
connective tissue of Albino rats (Histolopathological and Immunohistochemical Study). Cairo Dental Journal., (2004).

391 13. Darout, I.A., et al., Identification and quantification of some potentially antimicrobial anionic components in miswak extract. Indian Journal of Pharmacology, 32(1):

p.

$11-14$.

(2000).

https://scholar.google.com/scholar?q=Identification+and+quantification+of $+\mathrm{s}$ ome+potentially+antimicrobial+anionic+components+in+miswak+extract\&hl $=$ en\&as $\mathrm{sdt}=0 \&$ as vis $=1 \&$ oi $=$ scholart

397

398

14. Almas, K., Miswak (chewing stick) and its role in oral health. Postgraduate Dentist Middle East, 3(4): p. 214-18. (1993).

15. Al-Salman, T.H., M.G.A.S. Ali, and O.M. Al-Nu'aimy, The antimicrobial effect of water extraction of Salvadora persica (Miswak) as a root canal irrigant. Al-Rafidain Dental Journal, (1): p. 33-36 (2005). https://www.iasj.net/iasj?func=article \&aId $=45508$

16. El-Latif Hesham, A. and S.A. Alrumman, Antibacterial activity of miswak Salvadora persica extracts against isolated and genetically identified oral cavity pathogens. Technology and Health Care, 24(s2): p. S841-S848 (2016). https://content.iospress.com/articles/technology-and-health-care/thc1214

17. Wali B.N., Afifi, I.K., F. Balata, and N.A. Badr, Effect of An Experimental Mouth wash extracted from Miswak (Salvadora persica) on Cariogenic Bacteria and Dental Plaque Formation, 2018, International Journal of Current Research Vol. 10 (1), pp.64070-64075.

18. The plant material was identified by Dr. Talal Dahan, University of Bisha, Saudi Arabia. 
19. Adams, R.P., Identification of essential oil components by gas chromatography/mass spectrometry. Vol. 456. Allured publishing corporation Carol Stream, IL (2007). http://www.juniperus.org

20. Ayoub, I.M., et al., Volatile constituents of Dietes bicolor (Iridaceae) and their antimicrobial activity. Zeitschrift für Naturforschung C, 70(7-8): p. 217-225 (2015). https://www.degruyter.com/view/journals/znc/70/7-8/article-p217.xml

21. Elkady, W.M. and I.M. Ayoub, Chemical profiling and antiproliferative effect of essential oils of two Araucaria species cultivated in Egypt. Industrial Crops and Products, $\quad$ 118: $\quad$ p. $\quad 188-195$ https://www.sciencedirect.com/science/article/abs/pii/S0926669018302747

22. Gad, H.A., I.M. Ayoub, and M. Wink, Phytochemical profiling and seasonal variation of essential oils of three Callistemon species cultivated in Egypt. $\begin{array}{ll}\text { PloS } \quad \text { one, } & \text { 14(7) }\end{array}$ (2019). https://journals.plos.org/plosone/article?id=10.1371/journal.pone.0219571

23. Labib, R.M., et al., Appraisal on the wound healing potential of Melaleuca alternifolia and Rosmarinus officinalis L. essential oil-loaded chitosan topical preparations. $\quad$ PloS $\quad$ one, $14(9)$ (2019). https://journals.plos.org/plosone/article?id=10.1371/journal.pone.0219561

24. Ingle, J. and L. Bakland, Endodontics: Restoration of endodontically treated teeth (7th edn) BC Decker Inc Hamilton-London. 693 (2002).

25. Nair, P.R., et al., Intraradicular bacteria and fungi in root-filled, asymptomatic human teeth with therapy-resistant periapical lesions: a long-term light and electron microscopic follow-up study. Journal of endodontics, 1990. 16(12): p. 580-588 (1990). https://pubmed.ncbi.nlm.nih.gov/2094761/ 
26. Mônika, C.M. and I.C. Fröner, A scanning electron microscopic evaluation of different root canal irrigation regimens. Brazilian oral research, 20(3): p. 235240 (2006). https://www.scielo.br/scielo.php?script=sci $\operatorname{arttext\& pid=S1806-~}$ $\underline{83242006000300010}$

27. Chong, B. and T.P. Ford, The role of intracanal medication in root canal treatment. International endodontic journal, 25(2): p. 97-106 (1992). https://onlinelibrary.wiley.com/doi/abs/10.1111/j.1365-2591.1992.tb00743.x

28. Peters, L., P. Wesselink, and W. Moorer, The fate and the role of bacteria left in root dentinal tubules. International endodontic journal, 28(2): p. 95-99 (1995). https://pubmed.ncbi.nlm.nih.gov/7665208/

29. Sathorn, C., P. Parashos, and H. Messer, Australian endodontists' perceptions of single and multiple visit root canal treatment. International endodontic journal, 42(9): p. 811-818 (2009). https://pubmed.ncbi.nlm.nih.gov/19619228/

30. Bergenholtz, G., Pathogenic mechanisms in pulpal disease. Journal of endodontics, 16(2):

p. 98-101. https://www.sciencedirect.com/science/article/abs/pii/S0099239906815712 (1990).

31. Asnaashari, M., et al., Comparison of Antibacterial Effects of Photodynamic Therapy, Modified Triple Antibiotic Paste and Calcium Hydroxide on Root Canals Infected with Enterococcus Faecalis: An In-Vitro Study. Journal of Lasers in Medical Sciences, $\quad$ 10(4): $\quad$ p. 23-29. https://www.ncbi.nlm.nih.gov/pmc/articles/PMC6983872/ (2019).

32. Athanassiadis, B., et al., An in vitro study of the antimicrobial activity of some endodontic medicaments and their bases using an agar well diffusion assay. 

Australian
dental
journal,
54(2):
p.
141-146. https://www.ncbi.nlm.nih.gov/pmc/articles/PMC6983872/ (2009).

33. Al Qarni, F.M., et al., Antimicrobial activity of Azadirachta indica (neem) and Salvadora persica (miswak) extracts as endodontic irrigants. Endodontic Practice Today, 13(3) s\%20as\%20endodontic\%20irrigants\#.X4VRXNDXLIV (2019). http://www.quintpub.com/userhome/endo/endo-ept_13_3_al_p237.pdf

34. Hesham, A.E.-L. and S.A. Alrumman, Antibacterial activity of Miswak (Salvadora persica) extracts against isolated and genetically identified oral cavity pathogens. Technol Health Care,. 24: p. S841-SS84. https://content.iospress.com/articles/technology-and-health-care/thc1214 (2016)

35. Sofrata, A., et al., Benzyl isothiocyanate, a major component from the roots of Salvadora persica is highly active against Gram-negative bacteria. PLoS One, 6(8).

https://journals.plos.org/plosone/article?id=10.1371/journal.pone.0023045 (2011).

36. Nakamura, Y., et al., Involvement of the mitochondrial death pathway in chemopreventive benzyl isothiocyanate-induced apoptosis. Journal of Biological Chemistry, 277(10): $\quad$ p. $\quad$ 8492-8499. https://journals.plos.org/plosone/article?id=10.1371/journal.pone.0023045 (2002).

37. Patra, J.K., G. Das, and K.-H. Baek, Chemical composition and antioxidant and antibacterial activities of an essential oil extracted from an edible 
seaweed, Laminaria japonica L. Molecules, 20(7): p. 12093-12113. https://www.mdpi.com/1420-3049/20/7/12093 (2015)

38. Tunjung, W.A.S., D. Liana, and L. Hidayati, Antibacterial Activity and Composition of Crude Extracts of Kaffir Lime (Citrus hystrix DC.) Leaves and Callus. Proceedings of the Pakistan Academy of Sciences: B. Life and Environmental $\quad$ Sciences. $\quad$ 55(2): $\quad$ p. 45-53-45-53. http://www.ppaspk.org/index.php/PPASB/article/view/54

39. Nweze, C., H. Ibrahim, and G. Ndukwe, Beta-sitosterol with antimicrobial property from the stem bark of pomegranate (Punica granatum Linn). Journal of Applied Sciences and Environmental Management, 23(6): p. 1045-1049. https://www.ajol.info/index.php/jasem/article/view/188260 (2019).

40. Pu, Z.-H., et al., Antibacterial activity of 9-octadecanoic acid-hexadecanoic acid-tetrahydrofuran-3, 4-diyl ester from neem oil. Agricultural Sciences in China, 9(8):

p. 1236-1240. https://www.sciencedirect.com/science/article/abs/pii/S1671292709602121 (2010).

41. Chen, K.Y., et al., Monoacylglycerol of 7, 10-Dihydroxy-8 (E)-octadecenoic Acid Enhances Antibacterial Activities against Food-Borne Bacteria. Journal of agricultural and food chemistry,. 67(29): p. 8191-8196. https://pubs.acs.org/doi/abs/10.1021/acs.jafc.9b03063 (2019)

42. Memar, M.Y., et al., Carvacrol and thymol: strong antimicrobial agents against resistant isolates. Reviews in Medical Microbiology,. 28(2): p. 63-68. https://journals.lww.com/revmedmicrobiol/Abstract/2017/04000/Carvacrol an d thymol strong antimicrobial agents.4.aspx (2017) 
43. Ravi, L., et al., In vitro cytotoxicity of norviburtinal and isopinnatal from Kigelia pinnata against cancer cell lines. Asian Journal of Cell Biology, . 12(1): p. 158-164.

https://www.thieme$\underline{\text { connect.com/products/ejournals/abstract/10.1055/s-2000-9778 (2009) }}$

44. Rouis-Soussi, L.S., et al., Chemical composition and antibacterial activity of essential oils from the Tunisian Allium nigrum L. EXCLI journal. 13: p. 526. https://www.ncbi.nlm.nih.gov/pmc/articles/PMC4463966/ (2014)

45. Mazumder, K., et al., Bioactive Variability and In Vitro and In Vivo Antioxidant Activity of Unprocessed and Processed Flour of Nine Cultivars of Australian lupin Species: A Comprehensive Substantiation. Antioxidants. 9(4): p. 282. https://www.mdpi.com/2076-3921/9/4/282 (2020)

46. Rahman, M., et al., Antimicrobial compounds from leaf extracts of Jatropha curcas, Psidium guajava, and Andrographis paniculata. The Scientific World Journal, https://www.hindawi.com/journals/tswj/2014/635240/ (2014).

47. Lozano-Grande, M.A., et al., Plant sources, extraction methods, and uses of squalene. International journal of agronomy, 2018. https://www.hindawi.com/journals/ija/2018/1829160/ (2018).

48. Yusuf, A.J., et al., Antimicrobial activity of stigmasterol from the stem bark of Neocarya macrophylla. Journal of Medicinal Plants for Economic Development, 2(1): p. 1-5. https://journals.co.za/content/journal/10520/EJCdf2f206df (2018).

49. Yinusa, I., et al., Characterization and microbial activities of $\beta$-sitosterol and $\beta$-sitostenone mixture isolated from the stem bark of methanol fraction of Sarcocephalus latifolius (Smith Bruce). Int. Res. J. Nat. Sci. 2: p. 1-13. 
https://www.eajournals.org/journals/international-research-journal-of-naturalsciences-irjns/vol-2issue-2june-2014/characterization-microbial-activities\%ce\%b2-sitosterol-\%ce\%b2-sitostenone-mixture-isolated-stem-bark$\underline{\text { methanol-fraction-sarcocephalus-latifolius-smith-bruce/ (2014) }}$

50. Erdinest, N., et al., Anti-inflammatory effects of alpha linolenic acid on human corneal epithelial cells. Investigative ophthalmology \& visual science, . 53(8): p. 4396-4406. https://iovs.arvojournals.org/article.aspx? articleid=2168117 $\underline{(2012)}$

51. Yang, X., et al., Developmental toxicity of synthetic phenolic antioxidants to the early life stage of zebrafish. Science of the Total Environment. 643: p. 559568.

https://www.sciencedirect.com/science/article/abs/pii/S0048969718322897 $\underline{(2018)}$

52. Korkmaz, S., Antioxidants in maca (Lepidium meyenii) as a supplement in nutrition. Antioxidants in Foods and Its Applications, p. 138-154. https://www.intechopen.com/books/antioxidants-in-foods-and-itsapplications/antioxidants-in-maca-lepidium-meyenii-as-a-supplement-innutrition (2018).

53. Zai, J.A., et al., Methanol extract of Iphiona aucheri ameliorates CCl4 induced hepatic injuries by regulation of genes in rats. Toxicology Research, 8(6): p. 815-832. https://academic.oup.com/toxres/article-abstract/8/6/815/5709551 (2019).

54. Siddique, H.R. and M. Saleem, Beneficial health effects of lupeol triterpene: a review of preclinical studies. Life sciences,. 88(7-8): p. 285-293. 
558 55. Tyagi, T. and M. Agarwal, Phytochemical screening and GC-MS analysis of bioactive constituents in the ethanolic extract of Pistia stratiotes L. and Eichhornia crassipes (Mart.) solms. Journal of Pharmacognosy and phytochemistry,. 6(1): p. 195-206. (2017).

562

563

564

565

566

567

568

569

570

571

572

573

56. Fang, M., et al., Antibacterial activities of inorganic agents on six bacteria associated with oral infections by two susceptibility tests. International Journal of Antimicrobial Agents,. 27(6): p. $\quad$ 513-517. https://www.sciencedirect.com/science/article/abs/pii/S0099239907000064 (2006).

57. Phan, T.N., et al., Physiologic actions of zinc related to inhibition of acid and alkali production by oral streptococci in suspensions and biofilms. Oral microbiology and immunology,. 19(1): $\quad$ p. $31-38$. https://onlinelibrary.wiley.com/doi/abs/10.1046/j.0902-0055.2003.00109.x $(2004)$ 
Figures

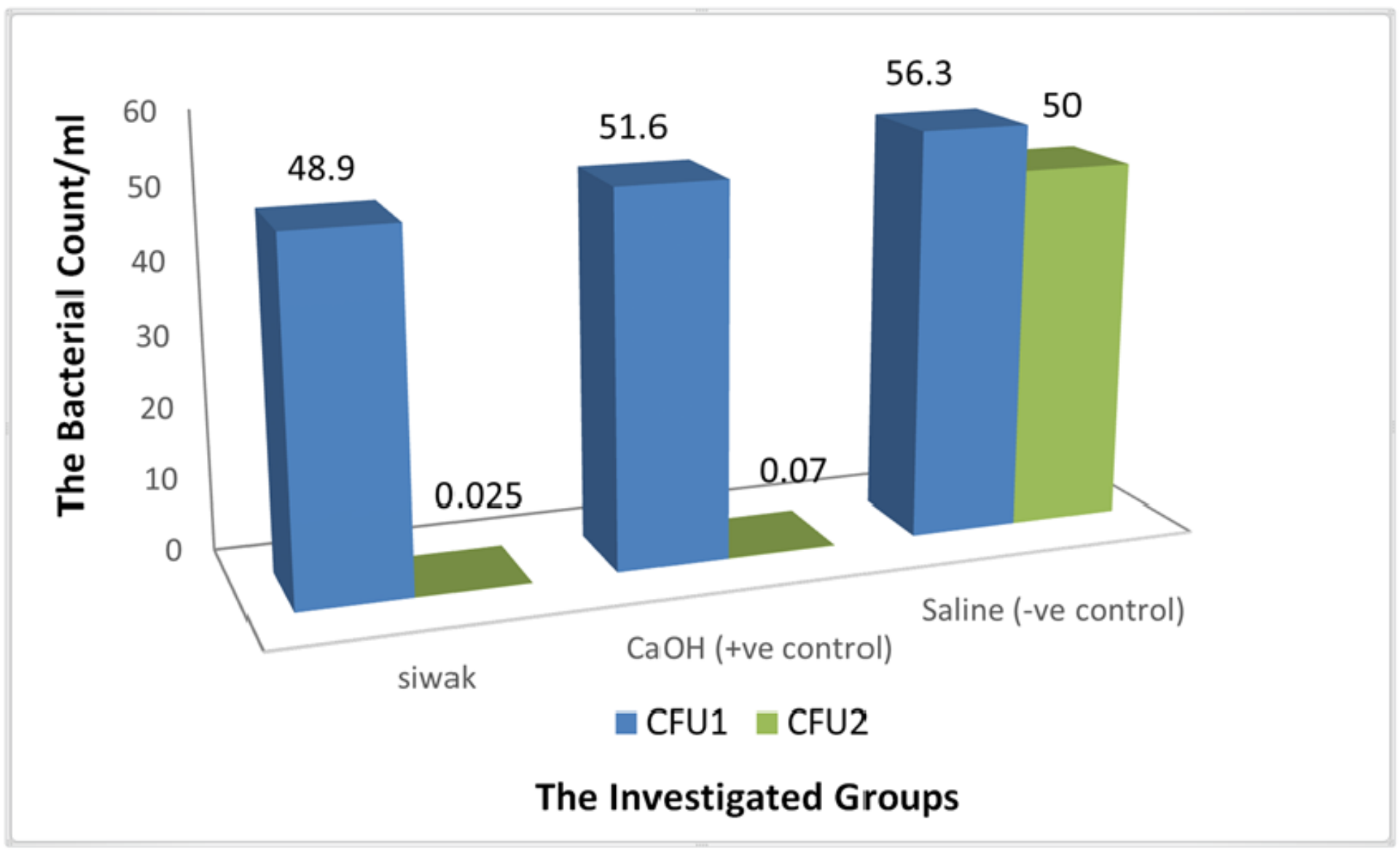

Figure 1

A histogram representing $\mathrm{CFU} / \mathrm{mL}^{\star} 104$ before and after application of intracanal medicaments

\section{Supplementary Files}

This is a list of supplementary files associated with this preprint. Click to download.

- Supplementaryfile.pdf 